\title{
MORPHOLOGICAL FEATURES OF THE BLEAK ALBURNUS ALBURNUS (L., 1758) FROM MIĘDZYODRZE
}

CECHY MORFOLOGI CZNEUKLEI ALBURNUS ALBURNUS (L., 1758) Z MIĘDZYODRZA

Department of marine Biological Resources, Agricultural University of Szczecin, Poland

17 meristic and morphometric features were studied in the bleak in the waters of Miedzyodrze. Noticeable positive or negative allometry was observed in the growth of head length, horizontal eye diameter, pelvic fins length, body height, and in the distance between pelvic fins and anal fin.

In the light of the studied features, the bleak in Miedzyodrze places itself in a transitional position between the lake populations and the riverine and estuarine populations.

\section{INTRODUCTION}

The bleak, inhabiting the rivers, lakes and estuaries of Central Europe, occurs abundantly in the waters of Poland (Myniec 1986). According to Kozikowska (1970), in Lake Mikołajskie during the 1960s the bleak was the second dominant species in catch after the bream. Formerly, it used to have certain economical importance as a source of guanine, obtained from its scales, and used for the production of "pearl essence" important for the cosmetic industry. Although it does not feature any economical importance nowadays, due to its small size, it remains important link in the trophic webs of the water ecosystems. Feeding on zooplankton, insect larvae and imagoes-captured from above the surface (see e.g. Terlecki et al. 1977; Chappaz et al. 1987; Białokoz 1990, 1997; Politou et al. 1992; Terlecki 1993) - it is a food competitor to adult and juvenile forms of many valuable fishes. Moreover, the bleak itself is the food of predatory fish species, e.g. pikeperch (among others Krzykawski and Szypuła 1982; Winkler 1989). 
The bleak also occurs in masses in the waters of Międzyodrze-the delta area situated above Szczecin which constitutes the greater part of the Lower Odra Valley Scenic Park. Although it does not appear in the commercial catches of the Fishery Co-operative "Regalica", exploiting these waters-obviously due to the selectivity of used fishing gear, constructed, in accordance with the regulations, to catch large, legal-size fish, mainly bream and pikeperch - in the experimental catches however, carried out with a small-mesh seine, the bleak made up about $40 \%$ of the number of all species specimens caught during the summer-autumn period.

So far the reports devoted to the bleak in the lower part of the River Odra have been scarce. There are few short communications pertaining to the bleak in the Szczecin Lagoon (among others Zimdars 1941; Pęczalska 1973, 1974). The extensive work of Gassowska (1974), dealing with the morphological features of bleak from various water bodies of Poland and their variability under ecological impact, also includes some data referring to the bleak in the Szczecin Lagoon as well as in the River Warta below Poznan - so in the two areas of the River Odra basin which lie below and above Międzyodrze, the area where no research on the bleak has yet been carried out. Moreover, the analysis of changes in the bleak body proportions with length growth is lacking in the literature. The aim of this paper is to narrow this gap through the analysis of the local bleak morphological features. The knowledge of the relationship between the dimensions of various body parts and the standard length will facilitate quite precise reconstruction of length (and thus weight) of the body, basing on any preserved fragments of the fish body found in predators stomachs.

\section{MATERIAL AND METHODS}

The fish to be examined were caught using a small-mesh seine of $10 \mathrm{~m}$ wing-spread. The hauls were carried out in the side branches of the River Regalica, the right arm of the Odra, near Gryfino, during the periods from May till October in 1996 and 1997. The bleak of different sizes occurred in nearly every haul, constituting in 1996 on the average about $40 \%$ of the total number of specimens caught. Totally, 405 bleak were caught. For the analysis of the morphological features, 202 best preserved specimens were selected (with the complete scale coating, intact fins etc.) measuring $17.5-105 \mathrm{~cm}$ of standard length $(S L)$.

The methods used for this research were identical to those applied by Gasowska (1974). The fish after catch was preserved in about $4 \%$ solution of formalin. The measurements of the bleak bodies were done according to the Pravdin's scheme (after Gasowska, 1962). Due to small size, the fish were measured under a stereo microscope, with measurement precision of $0.5 \mathrm{~mm}$. Also the lateral line scales and fin rays were counted under the stereo microscope. 
Table 1

Length frequency distribution of bleak caught in the Międzyodrze area

\begin{tabular}{|c|c|c|}
\hline$S L(\mathrm{~cm})$ & $\mathrm{n}$ & $\%$ \\
\hline 1.5 & 21 & 5.2 \\
2.0 & 62 & 15.3 \\
2.5 & 26 & 6.4 \\
3.0 & 75 & 18.6 \\
3.5 & 50 & 12.3 \\
4.0 & 13 & 3.2 \\
4.5 & - & - \\
5.0 & 1 & 0.2 \\
5.5 & 4 & 1.0 \\
6.0 & 14 & 3.5 \\
6.5 & 18 & 4.4 \\
7.0 & 17 & 4.2 \\
7.5 & 24 & 5.9 \\
8.0 & 23 & 5.7 \\
8.5 & 23 & 5.7 \\
9.0 & 17 & 4.2 \\
9.5 & 10 & 2.5 \\
10.0 & 6 & 1.5 \\
10.5 & 1 & 0.2 \\
\hline Total & 405 & 100.0 \\
\hline
\end{tabular}

Table 2

Frequency distribution of specimens with various number of lateral line scales in bleak from the Międzyodrze area. The mean number of lateral line scales $=49.368 \pm \mathrm{SD}=1.848$

\begin{tabular}{|c|r|r|}
\hline $\begin{array}{c}\text { Number of lateral } \\
\text { line scales }\end{array}$ & $\mathrm{n}$ & $\%$ \\
\hline 44 & 1 & 0.8 \\
45 & 1 & 0.8 \\
46 & 5 & 4.0 \\
47 & 12 & 9.6 \\
48 & 21 & 16.8 \\
49 & 23 & 18.4 \\
50 & 30 & 24.0 \\
51 & 20 & 16.0 \\
52 & 6 & 4.8 \\
53 & 4 & 3.2 \\
54 & 1 & 0.8 \\
55 & 1 & 0.8 \\
\hline Total & 125 & 100.0 \\
\hline
\end{tabular}

In the collected material the bleak measured 13-105 mm of $S L$ (Tab. 1), and one could easily notice two evidently discrete groups. The first were the specimens 13-42 mm long (modes: 20 and $30 \mathrm{~mm}$ ) and the second ranged 49-105 mm (mode $75 \mathrm{~mm}$ ). While measuring the morphometric features, both groups were treated separately, so to observe any possible differences in body proportions between the smaller and the larger fish. The significance of these differences was tested with the t-Student test. The first group was conventionally named "small" fish, whereas the other group-_"big" fish. The morphometric features were expressed as a percentage of $S L$, and additionally the correlations were analysed between the $S L$ and the other measured body distances.

\section{RESULTS}

\section{Meristic features}

The number of lateral line scales

The analysis of this feature was executable only for the "big" fish. As for the "small" fish, the scale coating was usually incomplete-because either the scales had not developed yet, or they partially or entirely fell off during the catch.

Among the 125 "big" fish the specimens had 44 to 55 scales on the lateral line (Tab. 2). The most common were the specimens with 50 lateral line scales (24\%). The average number of l.l. scales was $49.368 \pm 1.848$. 
Table 3 The number of anal fin rays

Frequency distribution of specimens with various number of soft rays in anal fin $(A)$

in bleak from the Międzyodrze area.

The mean number of soft rays $=17.482 \pm \mathrm{SD}=0.951$

\begin{tabular}{|c|r|r|}
\hline $\begin{array}{c}\text { Number of soft } \\
\text { rays in A }\end{array}$ & $\mathrm{n}$ & $\%$ \\
\hline 15 & 4 & 2.4 \\
16 & 23 & 13.7 \\
17 & 48 & 28.6 \\
18 & 75 & 44.6 \\
19 & 17 & 10.1 \\
20 & 1 & 0.6 \\
\hline Total & 168 & 100.0 \\
\hline
\end{tabular}

All of the 168 fish of $19-105 \mathrm{~mm}$ in length, being examined for this feature, had three hard rays. The number of the soft rays ranged between 15 and 20, and the most common were the fish with 18 rays $(44.6 \%$ of the examined specimens-Tab. 3). The average soft ray number in the anal fin amounted $17.482 \pm 0.951$.

The number of dorsal fin rays

All of the examined fish (168 specimens of 19 to $105 \mathrm{~mm}$ length) had 3 hard rays in their dorsal fins. The vast majority (157 specimens or $93.5 \%)$ had 8 soft rays. 9 soft rays were observed at 10 specimens $(6.0 \%)$, and there was one specimen with 7 soft rays $(0.5 \%)$. The average soft ray number in the dorsal fins was $8.0536 \pm 0.2502$.

\section{Morphometric features}

Table 4 displays the results of the 17 different bleak body distances measurements which were carried out separately for the "small" and the "big" fish and expressed as a percentage of $S L$. The differences between the mean values of all these 17 body proportions, computed for the "small" and the "big" fish, are statistically significant on the confidence level 0.001 . It implies a change in the body proportions in respect to $S L$ with the growth of length. The total length, fork length, head length, predorsal distance, dorsal fin base length, anal fin height, horizontal eye diameter relatively decrease with the increase of the body length. On the other hand the maximum body depth, minimum body depth, caudal peduncle length, postdorsal distance, dorsal fin height, pelvic and pectoral fin length, as well as distance $P-V$ and distance $V-A$ do relatively increase with the body length growth.

The correlation analysis between the discussed 17 measurements and $S L$ confirmed the above observations (Tab. 5). All the studied morphometric features are strongly correlated with the standard length what is shown by high values of the determination coefficients $\left(r^{2}\right)$.

The strongest correlation exists between the $S L$ and the total length as well as the fork length $\left(r^{2}\right.$ is close to 1$)$. The weakest correlation, still statistically significant, occurs between the $S L$ and the dorsal fin base length. 
Table 4

Some body measurements of the bleak Alburnus alburnus (L.) from the Miedzyodrze area expressed as a percentage of standard length: $\mathrm{A}-17.5-42 \mathrm{~mm}$; $\mathrm{B}-49-105 \mathrm{~mm} ; \mathrm{C}-17.5-105 \mathrm{~mm}$.

\begin{tabular}{|c|c|c|c|c|c|}
\hline \multicolumn{2}{|l|}{ Measurement } & Range & Mean & SD & $\mathrm{n}$ \\
\hline Total length & \begin{tabular}{|l|}
$\mathrm{A}$ \\
$\mathrm{B}$ \\
$\mathrm{C}$ \\
\end{tabular} & $\begin{array}{l}117.19-129.63 \\
117.33-123.66 \\
117.19-129.63\end{array}$ & $\begin{array}{l}121.46 \\
120.50 \\
120.86 \\
\end{array}$ & $\begin{array}{l}0.02 \\
0.01 \\
0.02\end{array}$ & $\begin{array}{r}76 \\
125 \\
201 \\
\end{array}$ \\
\hline Fork length & \begin{tabular}{|l|}
$\mathrm{A}$ \\
$\mathrm{B}$ \\
$\mathrm{C}$ \\
\end{tabular} & $\begin{array}{l}105.48-120.00 \\
105.06-112.90 \\
105.06-120.00\end{array}$ & $\begin{array}{l}110.69 \\
108.42 \\
109.28 \\
\end{array}$ & $\begin{array}{l}0.02 \\
0.01 \\
0.02 \\
\end{array}$ & $\begin{array}{r}76 \\
125 \\
201 \\
\end{array}$ \\
\hline $\begin{array}{l}\text { Maximum body } \\
\text { depth }\end{array}$ & $\begin{array}{l}\mathrm{A} \\
\mathrm{B} \\
\mathrm{C} \\
\end{array}$ & $\begin{array}{l}11.43-21.05 \\
17.14-25.00 \\
11.43-25.00 \\
\end{array}$ & $\begin{array}{l}17.77 \\
21.10 \\
19.83 \\
\end{array}$ & $\begin{array}{l}0.02 \\
0.02 \\
0.02\end{array}$ & $\begin{array}{r}77 \\
125 \\
202 \\
\end{array}$ \\
\hline $\begin{array}{l}\text { Minimum body } \\
\text { depth }\end{array}$ & \begin{tabular}{|l|}
$\mathrm{A}$ \\
$\mathrm{B}$ \\
$\mathrm{C}$ \\
\end{tabular} & $\begin{array}{l}5.56-9.33 \\
6.43-10.64 \\
5.56-10.64 \\
\end{array}$ & $\begin{array}{l}7.17 \\
8.15 \\
7.77 \\
\end{array}$ & $\begin{array}{l}0.01 \\
0.01 \\
0.01\end{array}$ & $\begin{array}{r}77 \\
125 \\
202 \\
\end{array}$ \\
\hline Head length & \begin{tabular}{|l|}
$\mathrm{A}$ \\
$\mathrm{B}$ \\
$\mathrm{C}$ \\
\end{tabular} & $\begin{array}{l}20.00-27.69 \\
18.39-24.39 \\
18.39-27.69 \\
\end{array}$ & $\begin{array}{l}23.50 \\
21.07 \\
22.00 \\
\end{array}$ & $\begin{array}{l}0.02 \\
0.01 \\
0.02\end{array}$ & $\begin{array}{r}77 \\
125 \\
202 \\
\end{array}$ \\
\hline $\begin{array}{l}\text { Caudal peduncle } \\
\text { length }\end{array}$ & \begin{tabular}{|l|}
$\mathrm{A}$ \\
$\mathrm{B}$ \\
$\mathrm{C}$ \\
\end{tabular} & $\begin{array}{l}15.38-24.32 \\
16.84-24.69 \\
15.38-24.69 \\
\end{array}$ & $\begin{array}{l}19.76 \\
20.49 \\
20.21 \\
\end{array}$ & $\begin{array}{l}0.02 \\
0.01 \\
0.02\end{array}$ & $\begin{array}{r}77 \\
125 \\
202 \\
\end{array}$ \\
\hline Predorsal distance & \begin{tabular}{|l|}
$\mathrm{A}$ \\
$\mathrm{B}$ \\
$\mathrm{C}$ \\
\end{tabular} & $\begin{array}{l}51.61-60.34 \\
45.71-57.83 \\
45.71-60.34 \\
\end{array}$ & $\begin{array}{l}54.67 \\
53.79 \\
54.13 \\
\end{array}$ & $\begin{array}{l}0.02 \\
0.01 \\
0.02 \\
\end{array}$ & $\begin{array}{r}77 \\
125 \\
202 \\
\end{array}$ \\
\hline $\begin{array}{l}\begin{array}{l}\text { Postdorsal } \\
\text { distance }\end{array} \\
\end{array}$ & $\begin{array}{l}\text { A } \\
\text { B } \\
\text { C } \\
\end{array}$ & $\begin{array}{l}27.59-39.39 \\
29.29-40.00 \\
27.59-40.00\end{array}$ & $\begin{array}{l}33.99 \\
35.86 \\
35.14 \\
\end{array}$ & $\begin{array}{l}0.02 \\
0.01 \\
0.02\end{array}$ & $\begin{array}{r}77 \\
125 \\
202 \\
\end{array}$ \\
\hline Dorsal fin height & $\begin{array}{l}\mathrm{A} \\
\mathrm{B} \\
\mathrm{C} \\
\end{array}$ & $\begin{array}{l}10.53-21.88 \\
15.29-20.11 \\
10.53-21.88\end{array}$ & $\begin{array}{l}17.30 \\
17.53 \\
17.45\end{array}$ & $\begin{array}{l}0.02 \\
0.01 \\
0.01\end{array}$ & $\begin{array}{r}77 \\
125 \\
202 \\
\end{array}$ \\
\hline $\begin{array}{l}\text { Dorsal fin base } \\
\text { length }\end{array}$ & \begin{tabular}{|l|}
$\mathrm{A}$ \\
$\mathrm{B}$ \\
$\mathrm{C}$ \\
\end{tabular} & $\begin{array}{l}7.14-15.79 \\
7.41-12.35 \\
7.14-15.79 \\
\end{array}$ & $\begin{array}{r}10.26 \\
9.88 \\
10.02 \\
\end{array}$ & $\begin{array}{l}0.02 \\
0.01 \\
0.01\end{array}$ & $\begin{array}{r}77 \\
125 \\
202 \\
\end{array}$ \\
\hline Anal fin height & \begin{tabular}{|l|}
$\mathrm{A}$ \\
$\mathrm{B}$ \\
$\mathrm{C}$ \\
\end{tabular} & $\begin{array}{l}10.53-16.22 \\
11.17-15.48 \\
10.53-16.22 \\
\end{array}$ & $\begin{array}{l}13.92 \\
13.69 \\
13.78 \\
\end{array}$ & $\begin{array}{l}0.01 \\
0.01 \\
0.01 \\
\end{array}$ & $\begin{array}{r}77 \\
125 \\
202 \\
\end{array}$ \\
\hline $\begin{array}{l}\text { Anal fin base } \\
\text { length }\end{array}$ & $\begin{array}{l}\text { A } \\
\text { B } \\
\text { C } \\
\end{array}$ & $\begin{array}{l}13.89-21.67 \\
15.71-21.84 \\
13.89-21.84 \\
\end{array}$ & $\begin{array}{l}18.52 \\
18.56 \\
18.55 \\
\end{array}$ & $\begin{array}{l}0.02 \\
0.01 \\
0.01\end{array}$ & $\begin{array}{r}77 \\
125 \\
202 \\
\end{array}$ \\
\hline Pectoral fin length & $\begin{array}{l}\mathrm{A} \\
\mathrm{B} \\
\mathrm{C}\end{array}$ & $\begin{array}{l}10.26-20.27 \\
15.45-21.33 \\
10.26-21.33 \\
\end{array}$ & $\begin{array}{l}15.85 \\
18.68 \\
17.60\end{array}$ & $\begin{array}{l}0.02 \\
0.01 \\
0.02\end{array}$ & $\begin{array}{r}77 \\
125 \\
202 \\
\end{array}$ \\
\hline Pelvic fin length & \begin{tabular}{|l|}
$\mathrm{A}$ \\
$\mathrm{B}$ \\
$\mathrm{C}$ \\
\end{tabular} & $\begin{array}{r}7.69-13.89 \\
11.43-15.76 \\
7.69-15.76 \\
\end{array}$ & $\begin{array}{l}11.07 \\
13.67 \\
12.68 \\
\end{array}$ & $\begin{array}{l}0.01 \\
0.01 \\
0.02 \\
\end{array}$ & $\begin{array}{r}77 \\
125 \\
202 \\
\end{array}$ \\
\hline Distance $P-V$ & \begin{tabular}{|l|}
$\mathrm{A}$ \\
$\mathrm{B}$ \\
$\mathrm{C}$ \\
\end{tabular} & $\begin{array}{l}18.33-26.92 \\
18.57-25.00 \\
18.33-26.92 \\
\end{array}$ & $\begin{array}{l}21.22 \\
21.89 \\
21.64 \\
\end{array}$ & $\begin{array}{l}0.02 \\
0.01 \\
0.02 \\
\end{array}$ & $\begin{array}{r}77 \\
125 \\
202 \\
\end{array}$ \\
\hline Distance $V-A$ & \begin{tabular}{|l|}
$\mathrm{A}$ \\
$\mathrm{B}$ \\
$\mathrm{C}$ \\
\end{tabular} & $\begin{array}{l}12.50-18.92 \\
15.00-21.61 \\
12.50-21.61 \\
\end{array}$ & $\begin{array}{l}15.45 \\
18.79 \\
17.52 \\
\end{array}$ & $\begin{array}{l}0.01 \\
0.01 \\
0.02 \\
\end{array}$ & $\begin{array}{r}77 \\
125 \\
202 \\
\end{array}$ \\
\hline $\begin{array}{l}\text { Horizontal eye } \\
\text { diameter }\end{array}$ & \begin{tabular}{|l|}
$\mathrm{A}$ \\
$\mathrm{B}$ \\
$\mathrm{C}$ \\
\end{tabular} & $\begin{array}{l}5.56-9.38 \\
5.24-7.69 \\
5.24-9.38 \\
\end{array}$ & $\begin{array}{l}7.66 \\
6.31 \\
6.82 \\
\end{array}$ & $\begin{array}{l}0.01 \\
0.01 \\
0.01 \\
\end{array}$ & $\begin{array}{r}77 \\
125 \\
202 \\
\end{array}$ \\
\hline
\end{tabular}


Table 5

Relationships between some body measurements $(y)$ and standard length $(x)$ in bleak (Alburnus alburnus (L.)) from Międzyodrze area expressed in the form of linear equation $y=a+b x$ (A) and the power equation $y=a x^{b}(\mathrm{~B})$.

\begin{tabular}{|c|c|c|c|c|c|c|c|c|c|c|}
\hline \multirow{3}{*}{\multicolumn{2}{|c|}{ Measurement }} & \multicolumn{9}{|c|}{ Standard length range } \\
\hline & & \multicolumn{3}{|c|}{$17.5-42 \mathrm{~mm}$} & \multicolumn{3}{|c|}{$49-105 \mathrm{~mm}$} & \multicolumn{3}{|c|}{$17.5-105 \mathrm{~mm}$} \\
\hline & & $a$ & $b$ & $r^{2}$ & $a$ & $b$ & $r^{2}$ & $a$ & $b$ & $r^{2}$ \\
\hline \multirow{2}{*}{ Total length } & & 0.6469 & 1.1917 & 0.9937 & 2.1545 & 1.1763 & 0.9950 & 0.6545 & 1.1949 & 0.9991 \\
\hline & & 1.2705 & 0.9866 & 0.9946 & 1.3447 & 0.9747 & 0.9960 & 1.2554 & 0.9904 & 0.9993 \\
\hline \multirow{2}{*}{ Fork length } & A & 1.1092 & 1.0672 & 0.9923 & 1.7547 & 1.0608 & 0.9954 & 1.1032 & 1.0689 & 0.9991 \\
\hline & & 1.2467 & 0.9645 & 0.9931 & 1.1928 & 0.9779 & 0.9956 & 1.1930 & 0.9778 & 0.9992 \\
\hline \multirow{2}{*}{$\begin{array}{l}\text { Maximum } \\
\text { body depth }\end{array}$} & 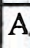 & -1.2880 & 0.2440 & 0.9415 & -5.0140 & 0.2780 & 0.9416 & -1.9390 & 0.2390 & 0.9823 \\
\hline & B & 0.0627 & 1.3083 & 0.9378 & 0.0528 & 1.3191 & 0.9447 & 0.0899 & 1.1980 & 0.9882 \\
\hline \multirow{2}{*}{$\begin{array}{l}\text { Minimum } \\
\text { body depth }\end{array}$} & & -0.2056 & 0.0790 & 0.8529 & -1.3120 & 0.0990 & 0.8903 & -0.5570 & 0.0890 & 0.9732 \\
\hline & $=$ & 0.0512 & 1.0985 & 0.8652 & 0.0309 & 1.2229 & 0.9017 & 0.0449 & 1.1374 & 0.9809 \\
\hline \multirow{2}{*}{ Head length } & A & 0.8 & 0.2046 & 0.8879 & 1.2910 & 0.1930 & 0.8941 & 1.1240 & 0.1960 & 0.9800 \\
\hline & B & 0.3544 & 0.8770 & 0.8979 & 0.3050 & 0.9143 & 0.8963 & 0.3395 & 0.8896 & 0.9841 \\
\hline \multirow{2}{*}{$\begin{array}{l}\text { Caudal pe- } \\
\text { duncle length }\end{array}$} & $\bar{A}$ & 0.2440 & 0.1890 & 0.8293 & 1.2780 & 0.1880 & 0.8403 & -0.1450 & 0.2060 & 0.9718 \\
\hline & $\mathrm{B}$ & 0.2 & 0.9496 & 0.8271 & 0.2659 & 0.9394 & 0.8554 & 0.1809 & 1.0271 & 0.9770 \\
\hline \multirow{2}{*}{$\begin{array}{l}\text { Predorsal } \\
\text { distance }\end{array}$} & $A$ & 0.5033 & 0.5290 & 0.9815 & -0.8980 & 0.5500 & 0.9780 & 0.2330 & 0.5360 & 0.9960 \\
\hline & & 0.5948 & 0.9748 & 0.9837 & 0.4797 & 1.0264 & 0.9767 & 0.5731 & 0.9855 & 0.9970 \\
\hline \multirow{2}{*}{$\begin{array}{l}\text { Postdorsal } \\
\text { distance }\end{array}$} & & -0.6356 & 0.3626 & 0.9284 & -0.0170 & 0.3590 & 0.9422 & -0.7350 & 0.3680 & 0.9896 \\
\hline & B & 0.2623 & 1.0764 & 0.9336 & 0.3661 & 0.9950 & 0.9395 & 0.2831 & 1.0542 & 0.9906 \\
\hline \multirow{2}{*}{$\begin{array}{l}\text { Dorsal fin } \\
\text { height }\end{array}$} & & -0.7170 & 0.1990 & 0.9053 & 0.1180 & 0.1740 & 0.9122 & -0.0530 & 0.1760 & 0.9829 \\
\hline & B & 0.0852 & 1.2094 & 0.8971 & 0.1790 & 0.9950 & 0.9212 & 0.1542 & 1.0305 & 0.9810 \\
\hline \multirow{2}{*}{$\begin{array}{l}\text { Dorsal fin } \\
\text { base length }\end{array}$} & & -0.0860 & 0.1060 & 0.6777 & -0.5710 & 0.1060 & 0.7670 & 0.0880 & 0.0980 & 0.9373 \\
\hline & D & 0.0777 & 1.0786 & 0.6939 & 0.0783 & 1.0526 & 0.7717 & 0.1062 & 0.9833 & 0.9410 \\
\hline \multirow{2}{*}{$\begin{array}{l}\text { Anal fin } \\
\text { height }\end{array}$} & & -0.2580 & 0.1490 & 0.9029 & 0.6520 & 0.1280 & 0.8784 & 0.1880 & 0.1340 & 0.9782 \\
\hline & 2 & 0.0978 & 1.1040 & 0.8996 & 0.1852 & 0.9299 & 0.8860 & 0.1430 & 0.9900 & 0.9814 \\
\hline \multirow{2}{*}{$\begin{array}{l}\text { Anal fin base } \\
\text { length }\end{array}$} & & -0.7010 & 0.2100 & 0.9048 & 0.2160 & 0.1830 & 0.8704 & 0.0280 & 0.1850 & 0.9766 \\
\hline & B & 0.1171 & 1.1353 & 0.9017 & 0.2146 & 0.9661 & 0.8723 & 0.1767 & 1.0116 & 0.9803 \\
\hline \multirow{2}{*}{$\begin{array}{l}\text { Pectoral fin } \\
\text { length }\end{array}$} & & -0.9170 & 0.1910 & 0.8874 & -0.3990 & 0.1920 & 0.8848 & -1.1600 & 0.2020 & 0.9798 \\
\hline & $D$ & 0.0635 & 1.2701 & 0.8800 & 0.1581 & 1.0381 & 0.8898 & 0.0882 & 1.1728 & 0.9808 \\
\hline \multirow{2}{*}{$\begin{array}{l}\text { Pelvic fin } \\
\text { length }\end{array}$} & & -0.6178 & 0.1328 & 0.8648 & -0.9570 & 0.1490 & 0.9137 & -1.1490 & 0.1520 & 0.9835 \\
\hline & $D$ & 0.0503 & 1.2329 & 0.8654 & 0.0875 & 1.1028 & 0.9224 & 0.0535 & 1.2157 & 0.9833 \\
\hline \multirow{2}{*}{ Distance $P-V$} & & 0.0686 & 0.2097 & 0.8613 & -1.5930 & 0.2400 & 0.9147 & -0.4750 & 0.2260 & 0.9808 \\
\hline & $D$ & 0.2207 & 0.9871 & 0.8756 & 0.1472 & 1.0914 & 0.9188 & 1.8820 & 1.0345 & 0.9839 \\
\hline \multirow{2}{*}{ Distance $V-A$} & A & -0.5820 & 0.1750 & 0.9044 & -1.8060 & 0.2120 & 0.9188 & -1.5600 & 0.2090 & 0.9844 \\
\hline & B & 0.0991 & 1.1311 & 0.9214 & 0.1112 & 1.1208 & 0.9190 & 0.0811 & 1.1927 & 0.9889 \\
\hline \multirow{2}{*}{$\begin{array}{l}\text { Horizontal } \\
\text { eye diameter }\end{array}$} & & 0.2460 & 0.0680 & 0.7584 & 1.6170 & 0.0420 & 0.6592 & 0.7450 & 0.0530 & 0.9351 \\
\hline & & 0.1063 & 0.9008 & 0.7885 & 0.2468 & 0.6840 & 0.6670 & 0.1488 & 0.8008 & 0.9512 \\
\hline
\end{tabular}

The application of a power equation to express the discussed relationships in all 17 cases resulted in a slightly better matching between the model and the empirical data than it was in the case of the linear equation. This is shown by higher determination coeffi- 
cients in the first case. What is more, applying the power equation confirmed the conclusion about the change in the bleak body proportions along with the increase of length-the conclusion drawn on the basis of the comparison between the means of the "small" fish and the "big" fish bodies measurements. Namely, the power indices $(b)$ are below or above onewhat reveals the occurrence of positive or negative allometry. The negative allometry occurs in the case of the total length (TL), fork length (FL), head length, predorsal distance, dorsal fin base length, anal fin height, and the horizontal eye diameter. The strongest negative allometry is visible in the case of the horizontal eye diameter and the head length (respective values of $b$ coefficient: 0.8008 and 0.8896 ). The positive allometry occurs in the case of maximum body depth, minimum body depth, caudal peduncle length, postdorsal distance, dorsal fin height, anal fin base length, pectoral and pelvic fins length, distance $P-V$, and distance $V-A$. The strongest positive allometry occurs in the case of pelvic fins length, maximum body depth, and distance $V-A$, what is displayed by the power $b$ coefficient values, considerably higher than 1 (respectively: 1.2157, 1.1980 and 1.1927Table 5). In the case of $T L$, the anal fin height, anal fin base length, caudal peduncle length, and dorsal fin height the observed allometry, positive or negative, is slight, as the $b$ coefficient values are close to one $(0.9904,0.9900,1.0116,1.0271$, and 1.0305 respectively). One can virtually treat the growth of these body portions as nearly isometric in respect to the $S L$.

The relationship between the anal fin base length and the number of its soft rays

\section{Table 6}

As has been dis-

Relative length of the base of anal fin $(A)$ in relation to the number of soft rays in bleak from the Międzyodrze area

\begin{tabular}{|c|c|c|c|r|}
\hline \multirow{2}{*}{$\begin{array}{c}\text { Number of soft } \\
\text { rays in } A\end{array}$} & \multicolumn{4}{|c|}{ Base length of $A$ in \% of $S L$} \\
\cline { 2 - 5 } & Range & Mean & SD & n \\
\hline 15 & $16.1-17.6$ & 16.75 & 0.69 & 4 \\
16 & $16.2-20.2$ & 18.60 & 0.99 & 23 \\
17 & $15.7-20.4$ & 18.29 & 1.02 & 48 \\
18 & $15.8-21.8$ & 18.65 & 1.23 & 75 \\
19 & $17.2-21.3$ & 19.36 & 1.28 & 17 \\
20 & - & 18.60 & - & 1 \\
\hline Total & $15.7-21.8$ & 18.55 & 0.013 & 168 \\
\hline
\end{tabular}
played in Table 6 , there is no clearly marked relationship between the number of anal fin soft rays and the anal fin base length. It may imply that if there are more rays, they are more delicate and situated closer to each

other. On the other hand, when the number of rays is smaller than the average, then they are thicker, and the spaces between them are bigger. 


\section{DISCUSSION}

Gassowska in her extensive article on the impact of the ecological factors on the biometric features of bleak (Gassowska 1974) stated that the existent differentiation of the features depends on the type of the water body and the thermal conditions of the environment. Among others, she asserted that the riverine bleak have generally less scales on the lateral line comparing to the bleak in lakes. Table 7, displaying the breakdown of the lateral line scales numbers for various bleak populations, reveals that the mean number of such scales for the bleak in Międzyodrze (49.37) is transitional between the high values characteristic for the lake populations and the low values typical for the riverine populations. Besides, the mean is distinctly lower than such mean value observed for the Szczecin Lagoon bleak, where the discussed feature has the mean being characteristic for the riverine populations. It must be stressed that the examined Międzyodrze waters often feature transitional character between the stagnant and running waters, and the current within this network of channels and river branches is very sluggish, strongly variable and dependant on the direction of wind and the water level in the main Odra arms: in the Regalica and the Odra Zachodnia.

Table 7

Number of lateral line scales in bleak from various bodies of water in Poland

\begin{tabular}{|l|l|r|c|c|}
\hline \multicolumn{1}{|c|}{ Body of water } & \multicolumn{1}{|c|}{ Source } & \multicolumn{1}{c|}{ Range } & M $\pm \mathrm{m}$ \\
\hline Lake Legińskie & Młyniec 1986 & - & $47-57$ & 51.2 \\
Lake Mikołajskie & Gąsowska 1974 & 70 & $48-55$ & $51.01 \pm 0.22$ \\
Lake Seksty & Gassowska 1974 & 100 & $47-55$ & $50.85 \pm 0.18$ \\
Lake Hańcza & Gąsowska 1974 & 120 & $48-53$ & $50.53 \pm 0.12$ \\
Lake Mamry & Gąsowska 1974 & 150 & $47-55(56)$ & $50.27 \pm 0.14$ \\
Lake Wdzydze & Gąsowska 1974 & 52 & $(47) 48-55(56)$ & $50.13 \pm 0.31$ \\
Międzyodrze & Kompowski - this work & 125 & $44-55$ & $49.37 \pm 0.17$ \\
River San & Gąsowska 1974 & 161 & $47-52$ & $49.21 \pm 0.08$ \\
Vistula Lagoon & Gąsowska 1974 & 41 & $47-53$ & $49.15 \pm 0.23$ \\
River Warta at Poznań & Gąsowska 1974 & 63 & $47-51$ & $49.12 \pm 0.04$ \\
Szczecin Lagoon & Gąsowska 1974 & 100 & $46-52$ & $48.50 \pm 0.16$ \\
Vistula at Kazimierz & Gąsowska 1974 & 100 & (45) 46-50 (51) & $48.08 \pm 0.11$ \\
\hline
\end{tabular}

Gasowska (1974) stated also that the riverine populations of bleak are characterised with, most frequently, higher mean number of anal fin soft rays than the lake populations. Table 8 shows that the mean number of the bleak soft rays in Miedzyodrze (17.48) is very close to the value observed by Gasowska (1974) in the bleak dwelling the River Warta below Poznań and in Lake Wdzydze. Gassowska recorded higher values of the discussed feature at the bleak in the Vistula near Kazimierz (18.05), whereas lower ones in the Vistula 
Lagoon and Szczecin Lagoon (respectively 17.27 and 17.16). The lowest mean number of the anal fin soft rays on the territory of Poland were observed by Mtyniec (1986) in Lake Legińskie (16.60).

Table 8

Number of anal fin soft rays in bleak from various bodies of water in Poland

\begin{tabular}{|l|l|r|c|c|}
\hline \multicolumn{1}{|c|}{ Body of water } & \multicolumn{1}{|c|}{ Source } & \multicolumn{1}{c|}{$\mathrm{n}$} & Range & $\mathrm{M} \pm \mathrm{m}$ \\
\hline Vistula at Kazimierz & Gąsowska 1974 & 100 & $16-21$ & $18.05 \pm 0.12$ \\
River San & Gąsowska 1974 & 161 & $(15) 16-21$ & $17.88 \pm 0.19$ \\
Lake Seksty & Gąsowska 1974 & 100 & $16-20$ & $17.75 \pm 0.21$ \\
Lake Mikołajskie & Gąsowska 1974 & 70 & $16-21$ & $17.55 \pm 0.08$ \\
Lake Wdzydze & Gąsowska 1974 & 52 & $16-19$ & $17.50 \pm 0.15$ \\
River Warta at Poznań & Gąsowska 1974 & 63 & $16-19$ & $17.50 \pm 0.01$ \\
Międzyodrze & Kompowski - this work & 168 & $15-20$ & $17.48 \pm 0.07$ \\
Vistula Lagoon & Gasowska 1974 & 41 & $16-19$ & $17.27 \pm 0.15$ \\
Lake Hańcza & Gąsowska 1974 & 120 & $(15) 16-19$ & $17.22 \pm 0.09$ \\
Szczecin Lagoon & Gąsowska 1974 & 100 & $15-20$ & $17.16 \pm 0.09$ \\
Lake Mamry & Gąsowska 1974 & 150 & $15-19(20)$ & $17.07 \pm 0.07$ \\
Lake Legińskie & Młyniec 1986 & - & $13-20$ & 16.6 \\
\hline
\end{tabular}

Considering the morphometric features, Gasowska (1974) stated that the bleak in the rivers have deeper body, larger head and shorter caudal peduncle length than the bleak in lakes. It should be kept in mind however that the changes in body proportions with growth can overlap the doubtless impact of the type of environment, this research showing that smaller bleak have relatively larger head, bigger horizontal eye diameter, shorter pelvic fins, smaller maximum body depth, and shorter distance between the pelvic and anal fins. The changes in body proportions with the length growth are common to fish and have been studied in detail, e.g. in common horse mackerel Trachurus trachurus (L., 1758) by Aloncle (1964). Therefore, using only morphometric features of the "big" fish for the comparisons with the bleak from other Poland's water bodies, one can see that-as far as the maximum body depth is concerned, reaching on the average $21.10 \% S L$ - the Miedzyodrze population is transitional between the lake populations (Lake Hańcza 19.46\%; Lake Dgał 18.58\%; Lake Mamry 19.98\%; Lake Mikołajskie 20.74\%—Gąsowska 1974; Lake Legińskie 19.3\%-Mtyniec 1986) and the riverine and estuarine populations (River Vistula 23.26\%; River Warta 23.63\%; Vistula Lagoon 23.50\%; Szczecin Lagoon 22.45\%—Gąsowska 1974). On the other hand however, some populations feature equally low body depth as lake populations (e.g. River San 20.65\%—Gassowska 1974).

As far as the relative head length is concerned, which for the Miedzyodrze bleak is on the average $21.07 \%$ of $S L$, it is quite a similar value to the head length of the bleak in the Szczecin Lagoon (20.95\% SL-Gassowska 1974), anyhow higher than the one of the most 
lake populations, either examined or quoted by the above mentioned author or by Myniec (1986) and lower then for the riverine populations, examined or quoted by these authors.

To sum up, one can state on the basis of the above discussion that the bleak of the population living in Międzyodrze occupies the transitional position, in respect to the morphological features, between the lake populations and the riverine or estuarine populations on the territory of Poland.

\section{CONCLUSIONS}

1. The bleak population in Międzyodrze is characterised by having 44-55 lateral line scales, with the mean $49.368 \pm 1.848$.

2. In the anal fin three hard rays and 15-20 (average 17.482 \pm 0.951 ) soft ones occurred.

3. The dorsal fins of the examined fish always had three hard rays and most frequently $(93.5 \%) 8$ soft rays. Incidentally, $9(6 \%)$ or $7(0.5 \%)$ soft rays were observed.

4. It was observed that the examined bleak featured changes in the body proportions with the length growth. Smaller bleak have relatively larger heads and bigger horizontal eye diameters than bigger fish (negative allometry) and shorter pelvic fins, lower body depths and the distances between the anal and pelvic fins (positive allometry).

5. The total length, anal fin height, anal fin base length, caudal peduncle length, and dorsal fin height grow nearly isometrically in relation to the $S L$.

6. There is no distinct relationship between the number of anal fin rays and its base length.

7. The bleak of the population inhabiting Międzyodrze occupy the transitional position, in respect to their morphometric features, between the lake populations and riverine or estuarine populations on the territory of Poland.

\section{REFERENCES}

Aloncle H., 1964: Note sur la croissance et quelques caractères numeriques de Trachurus trachurus (Linne, 1758) des cotes atlantiques du Maroc. Bull. Instit. Pêch. Marit. Maroc., 11: 25-38.

Białokoz W., 1990: Evaluation of the intensity and efficiency of bleak Alburnus alburnus (L.) feeding in Tajty Lake, Masurian Lakeland, Poland. Comparative analysis of methods. Ekol. Pol., 38, 2: 163-183.

Białokoz W., 1997: Intensywność i efektywność odżywiania się wybranych gatunków ryb [Intensity and effectiveness of feeding by selected fish species]. Arch. Ryb. Pol., 5, Suppl. 3: 5-36. (In Polish).

Chappaz R., G. Brun, G. Olivari, 1978: Mise en évidence de différeences de regime alimentaire dans une population d'ablettes Alburnus alburnus (L.) dans le lac de Sainto-Croix. Consequences sur la croissance et la fecondité. Annal. Limnol., 23: 245-252. 
Gąsowska M. (ed.), 1962: Klucze do oznaczania kręgowców Polski. Część I. Kragłouste Cyclostomi, Ryby - Pisces [Keys to determination of vertebrates of Poland. Part I. Cyclostomes-Cyclostomi, Fishes-Pisces]. PWN, Warszawa-Kraków. (In Polish).

Gąsowska Mo, 1974: Biometric and ecological studies on the bleak Alburnus alburnus (Linnaeus) (Pisces, Cyprinidae) from different bodies of water in Poland, in connection with the geograpfic variability of this species. Annal. Zool., 31, 4: 373-405.

Kozikowska Z., 1970: Analiza populacji ryb w jeziorach okolic Mikołajek na Mazurach [Analysis of fish populations in the lakes of the vicinity of Mikołajki, Masurian Lake District]. Acta Univ. Wratislav., 19, Prace Zool. 3: 1-119. (In Polish).

Krzykawski S., J. Szypula, 1982: Charakterystyka wzrostu i odżywiania się sandacza w jez. Dąbie i Regalicy w latach 1974-1977 [Growth and feeding of pikeperch in the Dąbie Lake and Reagalica River in 1974-1977]. Zesz. Nauk. AR Szczecin, 93, 12: 3-26. (In Polish).

Mlymiec B., 1986: Ukleja Alburnus alburnus (L., 1758) [Bleak Alburnus alburnus (L., 1758)]. In: Ryby słodkowodne Polski [Brylińska M. (ed.)]. PWN, Warszawa: 255-260. (In Polish).

Pęezallska A., 1973: Ichtiofauna Zalewu Szczecińskiego, jej specyfika i zmiany zachodzące w składzie gatunkowym ryb w powojennym 25-leciu [Ichthyofauna of the Szczecin Lagoon, its specifity and changes taking place in fish composition in the past 25 years]. Sympozjum Naukowe z okazji dwudziestolecia Oddziału MiR w Świnoujściu, Gdynia: 32-37. (In Polish).

Pẹczalska A., 1974: Niewykorzystane zasoby ryb w Zalewie Szczecińskim [Nonutilized fish resources in the Szczecin Lagoon]. Technika i Gospodarka Morska, 24, 4 (247): 205-206. (In Polish).

Politou C. J., P. S. Economidis, A. J. Sinis, 1993: Feeding biology of bleak, Alburnus alburnus, in Lake Koronia, northern Greece. J. Fish Biol., 43: 33-43.

Terlecki J., 1993: Zależności pokarmowe u małych ryb na przykładzie przybrzeżnej strefy nizinnego zbiornika zaporowego [Food relationships among small fish exemplified with nearshore zone of lowland dam reservoir]. Acta Acad. Agricult. Tech. Olst. Protectio Aquarum et Piscatoria, 19, Suppl. C: 1-58. (In Polish).

Terlecki J., J. A. Szczerbowski, A. Martymiuk, 1977: Pokarm leszcza, krapia, uklei i płoci w rzece Pisie Warmińskiej [The food of bream, white bream, bleak and roach in the Pisa Warmińska River]. Roczn. Nauk Roln., ser. H, 98, 2: 149-168. (In Polish).

Winkler H. M., 1989: The role of predators in fish communities in shallow coastal waters of the Southwest Baltic. Rapp. P.-v. Réun. Cons. Int. Explor. Mer, 190: 125-132.

Zimdars U., 1941: Die Fischerei des Stettiner Haffs und seiner Nebengewässer, geographisch betrachtet. Jahrbuch der Pommerschen Geographischen Gesellschaft, 59/60, Greifswald: 15136. 
Andrzej KOMPOWSKI

\section{CECHY MORFOLOGICZNE UKLEI ALBURNUS ALBURNUS (L., 1758) Z MIĘDZYODRZA}

\section{STRESZCZENIE}

Populacja uklei z Międzyodrza charakteryzuje się występowaniem od 44 do 55 husek na linii nabocznej; średnio $49,368 \pm 1,848$. Płetwa odbytowa zawierała zawsze trzy promienie twarde oraz 15 do 20 (średnio 17,482 $\pm 0,951$ ) promieni miękkich. Płetwa grzbietowa zbudowana była $\mathrm{z}$ trzech promieni twardych oraz 7-9 promieni miękkich (średnio 8,0536 $\pm 0,2502$ promieni).

Porównanie pomiarów 17 różnych odległości na ciele uklei, przeprowadzonych oddzielnie dla ryb o długości (SL) 17,5-42 mm („małe” ryby) oraz dla ryb o dhugości 49-105 mm („duże” ryby) i wyrażonych w \% $S L$, wykazało istnienie istotnych statystycznie różnic na poziomie istotności 0,001 między średnimi wartościami wszystkich 17 odległości obu grup wielkościowych.

Analiza korelacji między 17 pomiarami ciała i $S L$ uklei wykazało istnienie allometrii we wzroście tego gatunku ryb z Międzyodrza. „Małe” ukleje miały względnie większą głowę i większą poziomą średnicę oka, lrótsze płetwy brzuszne, mniejszą wysokość ciała oraz mniejszą odległość między płetwami brzusznymi i płetwą odbytową w porównaniu z uklejami „dużymi”.

Populacja uklei z wód Międzyodrza zajmuje pod względem badanych cech morfologicznych stanowisko pośrednie między populacjami jeziornymi oraz rzecznymi i zalewowymi z obszaru Polski.

Received: 24 August 1998

Author's address:

Andrzej Kompowski PhD DSc Prof Tit.

Department of Biological Marine Resources

Agricultural University of Szczecin

Kazimierza Królewicza 4, 71-550 Szczecin, Poland 